\title{
WÓJTOWA GÓRA W SIECIECHOWIE
}

SŁowa KLuCzowe: wieś Sieciechów; badania archeologiczne; średniowiecze; gród Sieciecha

KEYwords: village Sieciechów; archaeological research; Middle Ages; Sieciech's stronghold

\section{WSTĘP}

W roku 2012 minęło 140 lat od momentu wydania pracy Józefa Gackiego pt. Benedyktyński klasztor w Sieciechowie wedtug pism i podań miejscowych. Publikacja ta stanowi pierwszą i na dobrą sprawę jedyną po dzień dzisiejszy próbę monograficznego opracowania dziejów opactwa na szerokim tle historycznym sieciechowskiego zespołu osadniczego. Niestety, w przeciagu tych 140 lat stan naszej wiedzy o poszczególnych członach tego zespołu nie uległ zdecydowanemu poszerzeniu, gdyż nie stały się one przez ten czas przedmiotem szczegółowych studiów. Uwaga historyków, historyków architektury oraz archeologów skupiła się głównie wokół spraw miejscowego opactwa (Świechowski 2009: 245-247; Wiliński 1964; 1965; 1966), z rzadka tylko poruszając zagadnienia związane z jego szerszym tłem osadniczym (Wąsowiczówna 1959; Kowalczyk 1994). Podkreślić w tym miejscu jednak należy, iż badaniom mikroregionu sieciechowskiego nie sprzyjało już samo jego położenie w zalewowym terenie doliny Wisły. Liczne powodzie i zmiany koryta rzeki wpłynęły w znaczący sposób na zmianę topografii całej okolicy, co w sposób oczywisty powoduje szczególne trudności przy lokalizowaniu jego elementów osadniczych odnotowanych przez średniowieczne źródła pisane (Kowalczyk 1994: 76-79). Te elementy osadnicze to przede wszystkim castrum Sieciecha, o którym nie wiemy gdzie się mogło znajdować oraz jaka była jego relacja do późniejszego grodu kasztelańskiego. W dalszej kolejności wymienić tu także należy locus 
abbatiae, tj. miejsca lokalizacji pierwszego klasztoru benedyktyńskiego oraz wymieniony przez Jana Długosza zamek kazimierzowski (Wąsowiczówna 1959: 580; Kalina 2005: 284-285; Wróblewski 2006: 109-110).

W niniejszym artykule chciałbym zajać się pierwszemu z wymienionych powyżej obiektów, tj. grodem sieciechowskim, a dokładniej jedynym z miejsc jego hipotetycznej lokalizacji, czyli tytułową Wójtową Górą. Do podjęcia tego tematu zachęciła mnie możliwość spojrzenia na ten obiekt przez pryzmat źródeł dotychczas nie wykorzystywanych w kontekście badań nad tą problematyką, a umożliwiających, moim zdaniem, zweryfikowanie dawnych koncepcji oraz postawienie nowych hipotez.

\section{Stan BADAŃ}

Wójtowa Góra to niewielkie, piaszczyste wyniesienie położone na gruntach wsi Sieciechów, w odległości 2,5 km na zachód od centrum osady (tabl. I:1). W obrębie siatki ewidencyjnej AZP znajduje się ona na obszarze 71-73, a jej koordynaty kartograficzne na mapie topograficznej w skali 1:5000 (Mapa) określają wartości $Y-80$ oraz $X-10$. Całkowita powierzchnia wyniesienia nie przekracza 2 ha i odznacza się obecnie silnym przekształcona. Liczne zadokumentowane na jego terenie wybierzyska piasku, koncentrujące się głównie w centralnej części wyniosłości, pokrywają ok. $70-80 \%$ powierzchni obiektu. Obszarem wolnym od poważniejszych zniszczeń pozostaje jedynie południowy fragment wzniesienia, gdzie zadokumentowano pojedyncze, niewielkie wybierzyska. W chwili obecnej obszar stanowiska porastają łąki oraz młody las.

W dotychczas opublikowanych materiałach źródłowych nie natrafiono na ani jedną wzmiankę, którą można było by w sposób pewny powiązać z Wójtową Górą, a o relacjach omawianego stanowiska z wczesnośredniowieczną siecią osadniczą mikroregionu wnioskować możemy jedynie hipotetycznie, w oparciu o analizę nielicznych dwunasto- i trzynastowiecznych źródeł pisanych. Uzyskane z ich lektury dane przekonują, iż w XIII w., sieciechowski kompleks osadniczy składał się z wymienionego już powyżej grodu kasztelańskiego, klasztoru benedyktyńskiego, osady targowej oraz szeregu pomniejszych wsi. Problem lokalizacji grodu kasztelańskiego związany jest ściśle z zagadnieniem wzmiankowanej przez Galla (Anonim: II, 5, 16) warowni Sieciecha, i zgodnie z informacjami zawartymi we wstępie, nie doczekał się do dna dzisiejszego wyjaśnienia. Obok najpopularniejszej hipotezy, zakładającej tożsamość omawianego grodu ze wzniesieniem zwanym Wójtowa Góra (Wąsowiczówna 1959: 
572-574), w literaturze przedmiotu spotkać można także koncepcie opozycyjne, lokalizujące gród kasztelański na terenie Opactwa (Gacki 1872: 4), Łęgu Zajezierza (Sznuro 1966: 12-13; Kalinowska, Kalinowski 1973), Podobłocia (Kowalczyk 1994: 84-85, ryc. 3) czy Oleksowa-Sławczyna (Lechowicz 2011: 8). Nieco jaśniej przedstawiają się zagadnienia związane z położeniem wymienionego w źródłach locus abbatiae, tj. miejsca lokalizacji pierwszego klasztoru benedyktyńskiego. Odkrycie fragmentów romańskich ścian (Świechowski 2009: 247) ${ }^{1}$, ukrytych za prezbiterium kościoła klasztornego w Opactwie (Świechowski 2009: 245-247; Wiliński 1966: 198-200), zdaje się wskazywać, iż opactwo sieciechowskie od samego swego początku zlokalizowane było na terenie jednej z kęp nadwiślańskich, dziś nazywanej Opacką lub klasztorną. Nie jest to jednak koncepcja jedyna, gdyż w literaturze przedmiotu, spotkać można także poglądy odmienne, lokalizujące pierwsze opactwo sieciechowskie w obrębie wałów bliżej niesprecyzowanego grodu Sieciecha (Wąsowiczówna 1959: 578; Kłoczowski 1968: 400), lub na terenie Wójtowej Góry (Kiryk 1994: 129). Podobnych problemów z umiejscowieniem w terenie nie nastręcza trzeci, poza grodem i klasztorem, element wczesnośredniowiecznego zespołu sieciechowskiego, tj. osada targowa. Zdaniem zdecydowanej większości badaczy, wzmiankowany po raz pierwszy w 1253 r., lecz posiadający prawdopodobnie o wiele starszą metrykę (Wąsowiczówna 1959: 576), targ rozwijać się miał od samego swego początku wokół kościoła św. Wawrzyńca. Co prawda capella de Seczechow pojawia się w źródłach dopiero w 1191 r., aczkolwiek zdaniem części historyków parafia sieciechowska posiadać może nawet jedenastowieczną metrykę (Kiryk 1994: 129). Zgodnie z przekazem średniowiecznych źródeł pisanych, omówione powyżej główne człony zespołu osadniczego otoczone były wieńcem wsi, których w promieniu $15 \mathrm{~km}$ od centrum osady targowej funkcjonowało, co najmniej dwadzieścia. Większość z nich identyfikowalna jest w terenie do dnia dzisiejszego (por. Mozolice, Janików, Psary), a tylko nieliczne, jak np. Ostrów Mniejszy i Większy uznawane były już w XV w. za zaginione (Wiśniowski 1958: 41-45, mapa Posiadłości klasztoru...). W kontekście Wójtowej Góry, za najważniejsze uznać należy dwie ostatnie z wymienionych powyżej osad, gdyż zbieżność ich nazw, z toponimem pastwiska Ostrowa Wielka, zaznaczonego na XIX-wiecznej mapie Sieciechowa, w pobliżu Wójtowej Góry jest niezwykle sugestywna (Wąsowiczówna: 574-575). Podkreślić w tym miejscu także należy, iż po dzień dzisiejszy, część pół usytuowanych w najbliższej okolicy omawianego stanowiska nosi nazwę Ostrowce.

\footnotetext{
${ }^{1}$ Gdzie datowanie odkrytych reliktów na pierwsze trzydziestolecie XIII w.
} 
Pierwsza na Wójtową Górę zwróciła uwagę w roku 1956 Teresa Wąsowiczówna, utożsamiając ją w sposób jednoznaczny z reliktem wczesnośredniowiecznego grodu palatyna Sieciecha. Zdaniem badaczki, ten już wówczas, bardzo zniszczony obiekt, posiadał czytelne jeszcze w terenie relikty umocnień obronnych w postaci śladów nasypów i towarzyszących im rowów. Dodatkowym argumentem mającym uprawdopodobnić koncepcję o warownym charakterze odkrytych śladów osadnictwa wczesnośredniowiecznego była przesłanka toponomastyczna, związana z położoną w najbliższym sąsiedztwie stanowiska łąka, zwaną przez okoliczną ludność łąką grodziska (Wąsowiczówna 1959: 572-574; Dunin-Wąsowicz 1974: 39-41). Ceramika naczyniowa pozyskana w czasie planowych badań powierzchniowych oraz przeprowadzonych w latach 1956 i 1958 objazdów terenowych pozwoliła autorce wydatować to stanowisko na okres XI i XII w. Poglądy T. Wąsowicz spotkały się z akceptacją części środowiska naukowego (Cieślak-Kopyt, Micke, Skubicha, Twardowski 2004: 146-148), oraz w znaczący sposób wpłynęły na ukształtowanie świadomości historycznej mieszkańców Sieciechowa (Zając, Siek 2009: 8-10). Podkreślić w tym miejscy jednak należy, iż zaproponowana przez badaczkę koncepcja ma także i swoich oponentów. Przeciwniczką utożsamiania Wójtowej Góry z reliktami jakiegokolwiek obiektu obronnego jest Elżbieta Kowalczyk-Heyman (Kowalczyk 1994: 79). Badaczka ta, w oparciu o analizę źródeł kartograficznych, skłonna jest widzieć w omawianym wzniesieniu fragment starorzecza, a sekwencję nasypów i rowów łączoną przez T. Wasowiczównę z reliktami umocnień obronnych domniemanego grodu, z naturalnymi formami terenu wyerodowanymi przez rzekę. Autorki nie przekonują też przesłanki o charakterze toponomastycznym, gdyż jej zdaniem nazwy Wójtowa Góra i łąka grodziska rozpatrywane razem stanowią najprawdopodobniej odzwierciedlenie dawnych stosunków własnościowych.

Istnienia w omawianym miejscu grodu nie potwierdziły także nieliczne podejmowane dotychczas działania archeologiczne. Wojciech Twardowski po inspekcji konserwatorskiej piaśnic na Wójtowej Górze przeprowadzonej w 1968 r. stwierdziła tu jedynie istnienie cmentarzyska ciałopalnego z okresu wpływów rzymskich oraz „szeregu jam” z różnych okresów, począwszy od epoki brązu (kultura łużycka) po wczesne średniowiecze (Cieślak-Kopyt 19992001: 175-178; Balke 1991: 47, 85; Twardowski 1973: 23, 28: Cieślak-Kopyt; Micke, Skubicha, Twardowski 2004: 147-148). Badania AZP prowadzone na obszarze 71-73, Sieciechów, stan. IV(8) dostarczyły w stosunku do omawianego obiektu informacji o osadnictwie związanym z epoką brązu i śladów osadnictwa późnośredniowiecznego. Jednocześnie autor badan AZP nie potwierdził istnie- 
nia na Wójtowej Górze umocnień obronnych ${ }^{2}$. Kolejne, ostatnie jak dotychczas badania archeologiczne stanowiska przeprowadziła w roku 2002 Dorota Pogodzińska z Muzeum Regionalnego w Kozienicach. Analogicznie, jak w przypadku prac z roku 1968, tak i omawiane badania motywowane były nieustannym niszczeniem stanowiska wskutek nielegalnego poboru piasku. Podjęte działania ograniczyły się do narysowania profili obiektów archeologicznych widocznych w obrywach piaśnic oraz wytyczenia jednego niewielkiego wykopu ratowniczego. Wyniki przeprowadzonych prac nie potwierdziły obronnego charakteru stanowiska, a wręcz przeciwnie, zarejestrowane w czasie badań ślady osadnictwa średniowiecznego sklasyfikowane zostały przez autorkę badań jako związane z osadą otwartą (Solecka 2002: 1-2). Jednoznacznej odpowiedzi na pytanie o charakter stanowiska nie udzieliła archeologiczna prospekcja lotnicza obiektu przeprowadzona w roku 2010 przez pracowników i doktorantów Uniwersytetu Warszawskiego (Kowarska, Lenarczyk 2012a: 2, 11; 2012b: 3). Reliktów umocnień obronnych domniemanego grodu nie udało się także odnaleźć $\mathrm{w}$ trakcie objazdu terenowego przeprowadzonego w lipcu 2012 przez Zbigniewa Lechowicza z Łódzkiego Oddziału Narodowego Instytutu Dziedzictwa oraz Łukasza Reczulskiego z Instytutu Archeologii Uniwersytetu Łódzkiego.

Podjęcie próby weryfikacji hipotezy T. Wosowiczówny, pociąga za sobą konieczność ponownego zdefiniowania tak chronologii, jak i funkcjonalnego charakteru reliktów osadnictwa wczesnośredniowiecznego odkrytych w czasie dotychczasowych badań. Realizację tak sformułowanych postulatów badawczych oprzeć należy przede wszystkim o analizę dostępnych materiałów zabytkowych oraz dokumentacji terenowej. Sa to kroki o tyle konieczne, iż w dotychczasowych rozważaniach źródła tego typu analizowane były w niewielkim tylko zakresie, a materiały pozyskane w przeciągu ostatnich 15 lat nie stały się, jak do tej pory, przedmiotem rzeczowej analizy. Podkreślić jednak należy, iż dostępny do analizy materiał jest nieliczny i składa się z pojedynczych destruktów naczyń pozyskanych $\mathrm{w}$ drodze badań powierzchniowych oraz zbioru zabytków pochodzącego z wypełniska tzw. obiektu II (dalej: obiekt A) rozpoznanego w roku 2002. Tę skromną listę poszerzyć możemy jeszcze o kolekcję wczesnośredniowiecznej ceramiki naczyniowej znajdującą się obecnie w posiadaniu regionalisty Stefana Sieka ${ }^{3}$. Co prawda, materiały te pozyskane zostały w sposób amatorski, bez obecności archeologa, jednakowoż sporządzona przez S. Sieka dokumenta-

\footnotetext{
${ }^{2}$ Teczka AZP 71-73 w archiwum Działu Archeologii Narodowego Instytutu Dziedzictwa w Warszawie.

${ }^{3}$ Materiały te eksponowane są w sieciechowskiej izbie historyczno-regionalnej.
} 
cja $^{4}$ rysunkowo-fotograficzna częściowo zniszczonego obiektu (dalej: obiekt B), daje możliwość wykorzystania tych materiałów w charakterze źródeł archeologicznych (tabl. III:1-2).

Jak już wcześniej wielokrotnie wspomniano, stanowisko Wójtowa Góra jest od co najmniej półwiecza systematycznie niszczone wskutek nielegalnego wydobywania piasku. W roku 2002, na profilu jednej z piaśnic usytuowanej w południowej części stanowiska, D. Pogodzińska zainwentaryzowała zarys dużej jamy (obiekt $A$ ). W momencie przybycia na stanowisko archeologów, była ona już praktycznie zniszczona; to co pozostało, stanowiło tylko niewielki fragment pierwotnego jej zasięgu. Widoczna w profilu piaśnicy jama miała regularny kształt zwężający się ku dołowi. Na wypełnisko obiektu składała się czarna, tłusta, przesycona spalenizną próchnica, w spagowej części obiektu przemieszana z drobnymi węglami drzewnymi i większymi fragmentami przepalonego drewna. Zarys obiektu wyraźnie odcinał się od otaczającej warstwy jasnego piasku i sięgał na głębokości metra od współczesnej powierzchni gruntu. Dla sprawdzenia zasięgu poziomego jamy założono wykop o wymiarach wynoszących w przybliżeniu 1×2,5 m, dopasowany kształtem do zarysu piaśnicy. Obiektu $A$ widoczny był tuż pod grubą na $0,18 \div 0,20 \mathrm{~m}$ warstwą darni, i zarysował się półkoliście przy S-E narożniku wykopu (tabl. II:1). Niestety niewielkie rozmiary omawianej jednostki badawczej nie pozwoliły na pełne rozpoznanie obiektu, zinterpretowanego przez badaczkę jako jama odpadkowa (Solecka 2002: 2).

Druga z jam (obiekt B), rozkopana przez S. Sieka latem 1999 roku, usytuowana była analogicznie jak omówiony powyżej obiekt $A$, w obrębie południowej części stanowiska. Niestety, brak dokładnego planu sytuacyjno-wysokościowego uniemożliwia nam precyzyjną lokalizację przestrzenną obu obiektów. Jedynie na podstawie informacji ustnych uzyskanych od D. Pogodzińskiej i S. Sieka wnioskować możemy o przybliżonej ich lokalizacji i wzajemnych relacjach przestrzennych (tabl. I:2). Na podstawie udostępnionych mi zdjęć i odręcznych szkiców autorstwa regionalisty stwierdzić można, iż uwidoczniona w obrywie piaśnicy jama była szeroka na ok. $2 \mathrm{~m}$, a jej głębokość liczona od współczesnej powierzchni gruntu wynosiła 1,20 m. Obiekt posiadał nieckowaty kształt i zalegał bezpośrednio pod warstwą darni (tabl. III:1-2). Na wypełnisko jamy składała się przesycona spalenizną i węglami drzewnymi próchnica, przy czym stopień nasycenia popiołem i większymi fragmentami przepalonego drewna był na tyle wysoki, iż odkrywca przekonany był, iż ma do czynienia $\mathrm{z}$ reliktem paleniska.

\footnotetext{
${ }^{4}$ Dokumentacja ta to zwymiarowany szkic profilu obiektu, widocznego w obrywie wybierzyska oraz siedem fotografii.
} 


\section{RUCHOMY MATERIAL ZABYTKOWY ${ }^{5}$}

Dostępny do analizy materiał zabytkowy liczy 399 fragmentów naczyń glinianych, z czego 192 ułamki pozyskano z przebadanej części obiektu A, a pozostałe 207 pochodzi z obiektu B. Należy jednak podkreślić, iż liczba 207 fragmentów wiązanych z obiektem $B$ stanowi tylko część pozyskanego zbioru, a jego faktyczna liczebność jest w tym momencie niemożliwa do ustalenia. Homogeniczność zespołów naczyń wczesnośredniowiecznych jest w znacznym stopniu zakłócona przez obecność materiałów o charakterze rezydualnym, związanych z funkcjonujaccym na tym samym terenie osadnictwem pradziejowym. Z puli 399 fragmentów, 370 ułamków pochodziło z naczyń wczesnośredniowiecznych, a pozostałe 29 (7,2\%) powiązać należy z wcześniejszymi okresami dziejowymi; przede wszystkim wczesną epoką żelaza.

Wczesnośredniowieczne materiały ceramiczne pozyskane z obu obiektów odznaczają się znacznym stopniem fragmentacji; przeszło 80\% zabytków to fragmenty środkowych partii naczyń, a tylko niecałe $20 \%$ przypadło w udziale tzw. częściom charakterystycznym. Wśród tych ostatnich największy udział mają zabytki III kategorii wielkościowej wg. Andrzeje Buki (1979; 1990: 235244), stanowiące 71\% zbioru. Jako kategorię II sklasyfikowano 14,5\% ogółu zabytków, a jako I 13,5\%. Z pozyskanych ułamków udało się wykleić tylko jedno całe naczynie.

Wczesnośredniowieczne materiały ceramiczne z Wójtowej Góry, te pozyskane z wypełnisk obiektów $A$ i $B$, jak i te znalezione w czasie badań powierzchniowych czy inspekcji terenowych, tworzą zbiór niezwykle homogeniczny pod względem technologiczno-surowcowym. Wykonywano je na kole w technice taśmowo-ślizgowej, a następnie obtaczano starannie aż do linii dna. Tylko sporadycznie obtaczanie nie obejmowało partii przydennych. Do wyrobu naczyń używano glin żelazistych (rzadko kaolinowych lub biało wypalających się), w zdecydowanej większości chudych. Wypał odbywał się w atmosferze utleniającej, w wyniku czego naczynia nabierały najczęściej ceglasto-pomarańczowej lub brązowej barwy. Domieszka piasku używanego do schudzania gliny była zróżnicowana granulometrycznie, lecz ogólnie można ją scharakteryzować jako drobną, lub bardzo drobną. Wyjątkowo w charak-

\footnotetext{
${ }^{5}$ Za udostępnienie materiałów chciałbym w tym miejscu serdecznie podziękować Krzysztofowi Reczkowi dyrektorowi Muzeum Regionalnego w Kozienicach oraz Dorocie Pogodzińskiej autorce badań przeprowadzonych na stanowisku Sieciechów-Wójtowa Góra w roku 2002. Opracowywane materiały przechowywane są w magazynach wzmiankowanej powyżej placówki. Podziękowania należą się także Stefanowi Siekowi, założycielowi izby regionalno-historycznej w Sieciechowie.
} 
terze domieszki używano także kruszywa ceramicznego ${ }^{6}$. Glina używana do produkcji naczyń była bardzo dobrze oczyszczona; nie stwierdzono zanieczyszczenia przez margiel lub sieczkę organiczną, a obecność większych żwirów o granulacji $0,3 \div 0,5 \mathrm{~cm}$ zauważono tylko w przypadku pojedynczych fragmentów. Warto odnotować w tym miejscu także obecność w zbierze pojedynczych fragmentów prażnicy. Naczynie to wykonano niestarannie, z żelazistej gliny z bardzo dużą ilością organicznej domieszki schudzającej, widocznej zarówno w przekroju, jak i na powierzchni prażnic w postaci głębokich odcisków trzciny lub słomy.

Pod względem morfologicznym fragmenty naczyń z obiektów $A$ i $B$ tworzą niezwykle homogeniczny zespól złożony z ułamków stanowiących pozostałość dużych (Ø wylewów $15 \div 17 \mathrm{~cm}$ ), esowatych garnków charakteryzujących się krótką, ale mocno wciętą i wyodrębnioną szyjką oraz silnie profilowanym barkiem i brzuścem. Ze względu na proporcje naczyń oraz charakter połączeń zachodzący pomiędzy poszczególnymi elementami morfologicznymi, omawiany zbioru naczyń podzielić można na dwie podstawowe odmiany, tj.: I. egzemplarze wyróżniające się kątowym (ostrym) połączeniem pomiędzy poszczególnymi segmentami i wskaźniku wydętości brzuśca (Pankiewicz 2012: 39-407) oscylującym pomiędzy $1,54 \div 1,58$ (tab. tabl. II:2-3,5, IV:4-5,7,10). II. egzemplarze mające łagodniejszy profil i wskaźnik wydętości brzuśca oscylujący pomiędzy $1,20 \div 1,27$ (tabl. IV:2-3).

Największą różnorodnością w obrębie omawianego zbioru charakteryzuje się mikromorfologia wylewów, aczkolwiek i w tym przypadku poruszamy się w obrębie czterech głównych ich typów (tab. I). Krawędzie naczyń są silnie wywinięte na zewnątrz, poziome, zarówno proste jak i pogrubione. Większość zaopatrzona jest w okap, zaś do rzadkości należą wręby na pokrywkę.

Spośród 34 zarejestrowanych w zbiorze den, 20 sklasyfikować należy jako wklęsłe, a pozostałych 14 jako płaskie. W obrębie grupy den wklęsłych, 14 to egzemplarze z pierścieniem dookolnym, a pozostałe 6 bez pierścienia dookolnego. Średnice wszystkich den wahają się w przedziale od 8 do $9,5 \mathrm{~cm}$, przy czym, najliczniejszą grupę stanowią egzemplarze o średnicy oscylującej pomiędzy $8,5 \div 9 \mathrm{~cm}$. Obecność podsypki w postaci piasku odnotowano w 10 przypadkach, a tłucznia tylko w 2 . Na pozostałych 22 egzemplarzach nie zaobserwowano śladów stosowania podsypki. Wśród 25 poddanych analizie den, na których

${ }^{6}$ Za przeprowadzone ekspertyzy dziękuję Marcinowi Krystkowi z Muzeum Geologicznego Wydziału Nauk Geograficznych Uniwersytetu Łódzkiego.

${ }^{7}$ Wartość wyrażana stosunkiem średnicy największej wydętości brzuśca do średnicy szyjki. 
z całą pewnością stwierdzić można było obecność lub brak znaku garncarskiego, fragmentów naczyń znakowanych było 5 (tabl. I:4, II:8-9). We wszystkich przypadkach były to dna płaskie, a zainwentaryzowane symbole były wypukłe. W praktyce przesąadza to wtórnym charakterze znaków; najprawdopodobniej znakowane było koło garncarskie, aczkolwiek nie wolno nam w tym miejscu odrzucać potencjalnej dwukierunkowości działań garncarzy, którzy mieli być może na celu znakowanie zarówno naczyń, jak i koła garncarskiego. We wszystkich pięciu przypadkach dna zachowane były w stopniu umożliwiającym identyfikację symbolu, co pozwoliło wydzielić dwie zasadnicze ich kategorie, tj. a) krzyże (tabl. IV:9) i b) koła (tabl. II:4, IV:8).

Także pod względem stylistycznym, omawiane zespoły fragmentów wczesnośredniowiecznej ceramiki naczyniowej tworzą zbiór niezwykle homogeniczny. Za najpowszechniejszy sposób zdobienia powierzchni naczyń uznać należy połączenie ornamentu gęstych, dookolnych żłobków rytych lub częściej bruzd ${ }^{8}$ obejmujących $3 / 4$ powierzchni naczynia (ornament podstawowy) ze współwystępującym i podporządkowanym mu motywem ukośnych nacięć umieszczonych w miejscu przechodzenia górnej części brzuśca w szyjkę (tabl. II:2, IV:1-3, $4,7,10)$. Za o wiele rzadszy uznać należy ornament samych tylko zwielokrotnionych żłobków/bruzd lub pojedynczych linii rytych (tabl. II. 3, 5, IV:5-6).

\section{Analiza PORównawcza}

Przedstawiony powyżej materiał zabytkowy daje możliwość wyciągnięcia kilku wniosków związanych z chronologią stanowiska. Po pierwsze, analiza porównawcza przeprowadzona pomiędzy omawianym zbiorem, a zespołami ceramicznymi pozyskanymi w drodze badań prowadzonych na jedenastoi dwunastowiecznych, stanowiskach w Łęgu-Zajezierzu i Oleksowie-Sławczynie (Lechowicz 2011: 9-15; Kowalczyk 1994: 81), przekonuje o znacznym zaawansowaniu technologiczno-stylistycznym zespołu naczyń z Wójtowej Góry względem dwóch pozostałych. W świetle obowiązujących obecnie ustaleń (Buko 1990: 108; Chudziak 1967: 151-155; Hilczerówna 1967: 50-53), zakładających liniowy i niemalże ewolucyjny rozwój technologiczny wczesnośredniowiecznej

\footnotetext{
${ }^{8}$ Analizowany materiał zabytkowy dał podstawy do wydzielenia dwóch wariantów ornamentu w typie dookolnych żłobków/bruzd, gdyż w zależności od sposobu użycia rylca, garncarz był stanie uzyskać dwa całkowicie odmienne rodzaje zdobień. Pierwszym z nich były bruzdy powstałe w wyniku nacisku rylca trzymanego pod kontem ok. $90^{\circ} \mathrm{w}$ stosunku do powierzchni ścianek naczynia, co wiązało się z częściowym wyrywaniem gliny i odkładaniem jej po obu brzegach głębokiego żłobka (a - por. tabl. II:3, IV:2,6). Drugi sposób polegał na trzymaniu rylca pod kontem ok. $120^{\circ}$, co owocowało wciskaniem masy garncarskiej w ściankę naczynia, w rezultacie czego powstawała wygładzona, płytka bruzda (b - por. tabl. II:2,5, IV:1,3-5, 7, 10).
} 
ceramik słowiańskiej, wyrażający się w coraz powszechniejszym użyciu koła garncarskiego czy modyfikacji receptur garncarskich, zespół naczyń z Wójtowej Góry uznać należy za młodszy względem pozostałych. Po drugie, spoglądając na omawiany materiał z szerszej perspektywy, stwierdzić należy, iż uzyskany $\mathrm{z}$ wypełnisk obiektów $A$ i $B$ zestaw form ceramicznych jest niewątpliwie wczesnośredniowieczny i odnajduje bliskie analogie w naczyniach sklasyfikowanych przez Andrzeja Bukę jako V rodzina form ceramiki sandomierskiej (Buko1981: 153-155, ryc. 51) ${ }^{9}$, czy typie IV wczesnośredniowiecznej ceramiki małopolskiej wg. Andrzeje Żakiego (1974: 184). Zdaniem obu badaczy, formy analogiczne względem analizowanych i charakteryzujące się zbieżnymi cechami technologiczno-stylistycznymi datować należy na okres XII i 1. poł. XIII w. (Buko 1981: $72-73,195)$. Dalsza analiza zasięgu ich występowania wykazuje, iż zbiór ceramiki z Wójtowej Góry wpisuje się w ramy szerszego zjawiska charakterystycznego dla garncarstwa XII-XIII-wiecznej Polski. Formy naczyń zbliżonych pod względem technologiczno-stylistyczno-morfologicznym do analizowanych bez trudu odnaleźć można w publikowanych materiałach z terenu Mazowsza, Wielkopolski, Śląska czy ziemi radomskiej (Buko 1981: 196; Kaźmierczyk 1970: 431-434, ryc. 125a, c, f-g, i; Lechowicz 2010: 98-102, ryc. 1a: 4-6; Poliński 1996: 193). Za elementy przemawiające za młodszą metryką zbioru, zbliżające jego chronologię do 2. poł. XIII lub nawet początków XIV w., uznać należy bogaty zestaw krawędzi wylewów odnajdujący bliskie analogie w wytworach garncarzy późnośredniowiecznych (tabl. I) (Kruppé 1981: tabl. 1:18, 5:2, 7:1,11, 18:20, 19:5, 21:6, 22:15, 27:2, 9, 29:2).

W uściśleniu chronologii obiektów nie pomogą nam pojedyncze fragmenty prażnicy, gdyż naczynia tego typu cechują się długowiecznością i występują w niezmienionej formie na obszarze całej Polski, jak również Czech, Rusi i wschodnich Niemiec, przez niemal cały okres wczesnego średniowiecza, po wiek XIII włącznie (Malinowski 1957/58: 78-79; 1970: 332).

\section{Podsumowanie}

Podczas dotychczasowych działań archeologicznych prowadzonych na stanowisku Sieciechów-Wójtowa Góra wyróżniono kilkanaście różnego rodzaju obiektów o charakterze osadniczym, z których tylko nieliczne wiązać można z okresem wczesnego średniowiecza (obiekty $A$ i B). Niewielki zasięg badań i ich charakter, nie pozwalają na pełne wnioskowanie odnośnie zasięgu i rozplanowania osadnictwa wczesnośredniowiecznego, jednakże, na podstawie rozrzutu

\footnotetext{
${ }^{9}$ Grupa naczyń o średniej wydętości brzuśca i wyraźnie wyodrębnionej szyjce.
} 
powierzchniowych znalezisk ceramiki sądzić można, iż zajmowało ono w tym okresie całą przestrzeń piaszczystego wyniesienia. Wyniki dotychczasowych badań wykopaliskowych i powierzchniowych, wsparte analizą profili licznych wybierzysk piasku, nie potwierdziły istnienia na terenie Wójtowej Góry umocnień obronnych w postaci reliktów wału. W świetle dostępnych danych, na terenie omawianego stanowiska funkcjonowało osadnictwo o charakterze wyłącznie otwartym $^{10}$, a jego chronologię $\mathrm{w}$ oparciu o analizę materiału ceramicznego, określić można na wiek XIII, lub początek wieku XIV. Charakter wypełnisk obu omawianych w tej pracy obiektów wczesnośredniowiecznych, oraz niezwykła jednorodność materiałów zabytkowych z nich pozyskanych, zdają się przemawiać za zbieżną chronologią obu struktur, oraz zbliżonym charakterze procesów odpowiedzialnych za ich powstanie. Co do pierwotnej ich funkcji, nie przekonują koncepcje identyfikujące obiekt $A$ z jamą odpadkową, a obiekt $B$ z paleniskiem. Znaczne rozmiary obu jam, oraz zadokumentowana w podrysie, owalna forma obiektu A, zdają się wskazywać na mieszkalny charakter obu reliktów. Brak wypłaszczonego dna wyklucza funkcję ziemianki i wskazuje iż mamy tu raczej do czynienia z partiami piwnicznymi budynków naziemnych. Niestety, skąpe dane jakimi dysponujemy odnośnie morfologii obu obiektów, w znaczący sposób rzutują na zaproponowaną powyżej interpretację funkcjonalną.

Przypuszczalnie, omawiane relikty osadnictwa wczesnośredniowiecznego stanowią pozostałość po którejś z siedmiu wsi (być może Ostrowa Mniejszego lub Większego), rozlokowanych w najbliższym sąsiedztwie klasztoru sieciechowskiego, które w ciagu 2. poł. XIII i lub w początkach wieku XIV, uległy zniszczeniu w wyniku najazdów tatarskich (Kowalczyk 1994: 83; Wiśniowski 1958: 45). Hipoteza ta, prawdopodobna, lecz trudna na chwilę obecną do w pełni przekonywującego dowiedzenia, wyznaczała by nam rok 1241 jako terminus post quem dla procesu depozycji przeanalizowanych $\mathrm{w}$ niniejszym szkicu materiałów.

mgr Łukasz Reczulski

Uniwersytet Łódzki

Wydział Filozoficzno-Historyczny

Katedra Archeologii Historycznej i Bronioznawstwa

Instytut Archeologii

ul. Uniwersytecka 3

90-137 Łódź

\footnotetext{
${ }^{10}$ Podkreślić w ty miejscu należy, iż opłakany stan zachowania obiektu sprawia że definitywne odrzucenie koncepcji Teresy Wąsowiczówny, lokalizującej w omawiany miejscu gród Palatyna Sieciech jest w chwili obecnej niemożliwe. Relikty domniemanego grodu mogły po prostu ulec zniszczeniu w efekcie wybierania piasku z centralnej, najbardziej zniszczonej części obiektu.
} 


\section{Bibliografia}

Źródła

Anonim, (1952), Anonim tzw. Gall. Cronica et gesta ducum sive principum polonorum, wyd. K. Maleczyński, „Monumenta Poloniae Historica” series nova, t. II, s. 2-112.

Mapa (1996), Mapa topograficzna Polski, skala 1:5000, ark. M-34-20-A Kozienice, Warszawa.

Opracowania

Balke B. (1991), Kultura przeworska w międzyrzeczu Wisty, Pilicy i Itżanki, COBOAPEW, Agencja Ekspertyz, Projektów i Wydawnictw, Warszawa.

Buko A. (1979), Problem analizy opisowej wyrobów garncarskich zachowanych fragmentarycznie, „Kwartalnik Historii Kultury Materialnej”, R. XXVII, nr 2, s. 187-207.

Buko A. (1981), Wczesnośredniowieczna ceramika sandomierska, Ossolineum, Wrocław.

Buko A. (1990), Ceramika wczesnopolska. Wprowadzenie do badań, Ossolineum, Wrocław.

Chudziak W. (1991), Periodyzacja rozwoju wczesnośredniowiecznej ceramiki $z$ dorzecza dolnej Drwęcy (VII-XI/XII w.). Podstawy chronologii procesów zasiedlania, Civitas, Torun.

Cieślak-Kopyt M. (2001), Materiały ze zniszczonego cmentarzyska kultury przeworskiej w Sieciechowie, pow. Kozienicki, woj. Mazowieckie, stan. „Wójtowa Góra”, „Wiadomości Archeologiczne”, t. LIV, s. 175-178.

Cieślak-Kopyt M., Micke I., Skubicha E., Twardowski W. (2004), Radomskie - Alfabet Wykopalisk. Przewodnik archeologiczny, Wydawnictwo Instytutu Technologii Eksploatacji, Muzeum im. Jacka Malczewskiego, Radom.

Dunin-Wąsowicz T. (1974), Zmiany w topografii osadnictwa wielkich dolin na niżu środkowo-europejskim w XIII wieku, Ossolineum, Wrocław.

Gacki J. (1872), Benedyktyński klasztor $w$ Sieciechowie wedlug pism i podań miejscowych, Drukarnia J. Trzebińskiego, Radom.

Hilczerówna Z. (1967), Dorzecze górnej i środkowej Obry od VI do poczatków XI wieku, Ossolineum, Wrocław.

Kalina D. (2005), Pozostałe zamki i rezydencje królewskie na terenie dawnego województwa sandomierskiego. Wstęp do badań, [w:] Późnośredniowieczne zamki na terenie dawnego województwa sandomierskiego, red. L. Kajzer, Krajowy Ośrodek Badań i Ochrony Zabytków w Warszawie, Regionalny Ośrodek Badań i Ochrony Zabytków w Kiecach, Kielce, s. 211-303. 
Kalinowska E., Kalinowski W. (1973), Zaginione grodziska w Radomskim (Skaryszew i Sieciechów), „Kwartalnik Historii Kultury Materialnej”, R. XXI, nr 2, s. 244-246.

Kaźmierczyk J. (1970), Wrocław lewobrzeżny we wczesnym średniowieczu, cz. II, Ossolineum, Wrocław.

Kiryk F. (1994), Urbanizacja Małopolski. Województwo sandomierskie. XIII-XVI wiek, regionalny Ośrodek Studiów i Ochrony Środowiska Kulturowego, Kielce.

Kłoczowski J. (1968), Zakony na ziemiach polskich $w$ wiekach średnich, [w:] Kościót $w$ Polsce, t. 1. Średniowiecze, red. J. Kłoczowski, ZNAK, Kraków, s. $375-582$.

Kowalczyk E. (1994), Powracajacy temat: Sieciechów. Z problematyki organizacji grodowej w Polsce wczesnośredniowiecznej, „Kwartalnik Historii Kultury Materialnej", R. XLII, nr 1, s. 69-85.

Kowarska Z., Lenarczyk Sz. (2012a), W poszukiwaniu legendarnego grodu Sieciecha, cz. I, „CzasoPISMO KOZIENICKIE OKO”, nr 3, s. 2.

Kowarska Z., Lenarczyk Sz. (2012b), W poszukiwaniu legendarnego grodu Sieciecha, $c z$. II, „CzasoPISMO KOZIENICKIE OKO”, nr 4, s. 3.

Kruppé J. (1981), Garncarstwo późnośredniowieczne w Polsce, Ossolineum, Wrocław.

Lechowicz Z. (2010), Wyniki badań na stan. 1 w Gniazdkowie gm. Chotcza, pow. lipski, woj. mazowieckie, przeprowadzonych $w$ latach 1985-1988, [w:] Radom $i$ region radomski $w$ świetle badań archeologicznych, red. M. CieślakKopyt, K. Solarska, „Biuletyn Kwartalny Radomskiego Towarzystwa Naukowego", t. XLIV, z. 1-4, s. 87-108.

LechowiczZ. (2011), Dzieje ziemi radomskiej w średniowieczu. Okręg grodowy w Skrzynnie, Miejska Biblioteka Publiczna im. Józefa A. i Andrzeja S. Załuskich, Radom.

Malinowski T. (1958), Wczesnośredniowieczne prażnice $w$ Wielkopolsce, „Przegląd Archeologiczny", t. 9, s. 68-79.

Malinowski T. (1970), Prażnice, [w:] Słownik Starożytności Słowiańskich, T. 4, P-R, red. G. Labuda, Z. Stieber, Ossolineum, Wrocław, s. 332.

Twardowski W. (1973), Dziat archeologiczny, [w:] 50 lat Muzeum Regionalnego. w Radomiu. Informator, red. A. Apanowicz, W. Twardowski, Muzeum Regionalne, Radom, s. 19-35.

Pankiewicz A. (2012), Relacje kulturowe południowego Ślaska i pótnocnych Moraw $i$ Czech w IX-X wieku w świetle źródet ceramicznych, Wydawnictwo Uniwersytetu Wrocławskiego, Wrocław.

Poliński D. (1996), Przemiany w wytwórczości garncarskiej na ziemi chetmińskiej u schyłku wczesnego i na poczatku późnego średniowiecza, „Archaeologia Historica Polona", t. 4, Torun. 
Solecka D. (2002), Sprawozdanie z badań ratowniczych przeprowadzonych $w$ Sieciechowie - Wójtowej Górze, maszynopis sprawozdania w Archiwum Muzeum Regionalnego w Kozienicach, Kozienice.

Sznuro H. (1966), Grodziska w Radomskim, „Biuletyn Kwartalny Radomskiego Towarzystwa Nauk", t. III, z. 1, s. 1-24.

Świechowski Z. (2009), Katalog architektury romańskiej w Polsce, Wydawnictwo DiG, Warszawa.

Wąsowiczówna T. (1959), Topografia wczesnośredniowiecznego Sieciechowa, „Przegląd Historyczny", t. 50, z. 3, s. 567-581.

Wiliński S. (1964), Sprawozdanie z badań w 1961 - Sieciechów opactwo, Zespół badań nad Polskim Średniowieczem Uniwersytetu Warszawskiego i Politechniki Warszawskiej. Sprawozdania 1961, red. W. Antoniewicz, P. Biegański, PWN, Warszawa, s. 123-124.

Wiliński S. (1965), Badania architektoniczno-archeologiczne na stanowisku Sieciechów-Opactwo, pow. Kozienice za lata 1962 i 1963 r., Zespół badań nad Polskim Średniowieczem Uniwersytetu Warszawskiego i Politechniki Warszawskiej. Sprawozdania 1962-1963, red. W. Antoniewicz, P. Biegański, PWN, Warszawa, s. 86-88.

Wiliński S. (1966), Badania archeologiczno-architektoniczne w Sieciechowie-Opactwie $w$ latach 1961-1964, Zespół badań nad Polskim Średniowieczem Uniwersytetu Warszawskiego i Politechniki Warszawskiej, Sprawozdania 1966, red. W. Antoniewicz, P. Biegański, PWN, Warszawa, s. 193-203.

Wiśniowski E. (1958), Z dziejów opactwa Benedyktynów w Sieciechowie, „Roczniki Humanistyczne", t. 7, z. 2, s. 23-122.

Wróblewski S. (2006), Zamki i dwory obronne województwa sandomierskiego w średniowieczu, Wydawnictwo Goldruk, Nowy Sącz.

Zając K., Siek S. (2009), Sieciechów. Szkice do dziejów miejscowości od czasów najdawniejszych do współczesnych, Skaut.PL Dariusz Mariusz Zając, Kozienice-Sieciechów.

Żaki A. (1974) Archeologia Małopolski wczesnośredniowiecznej, Prace Komisji Archeologicznej, t. 13, Ossolineum, Wrocław. 
SUMMARY

\section{WÓJTOWA HILL IN SIECIECHÓW}

The history of Sieciechów and located monuments on its area for over 140 years are the subject of intensive research by historians, architectural historians and archaeologists. Particular attention is drawn primarily researchers station called Mountain village mayors - a small (now almost totally destroyed) hill situated west of the center of today's settlement, considered by some researchers for the location of the well-known from written sources castrum Sieciech.

This article discusses how far unpublished materials relating to this position, which is a collection of 399 pieces of pottery derived from within two archaeological sites located in the southern part Wójtowa Mountains. Analysis of these artifakts has allowed the protrusion of a new and different about the current interpretation of the functional position. Now, as a result of the analysis of these materials, and correlating the information obtained in this way with the data on the stratigraphy of the hill, the view of past defensive been denied a Wójtowa Mountains. In the light of the development of this material in position to function only of an open settlement, and the chronology based on the analysis of the ceramic material, can be determined by the age XIII, XIV or early age. Presumably, discussed the settlement was destroyed by the Tartar invasion. 

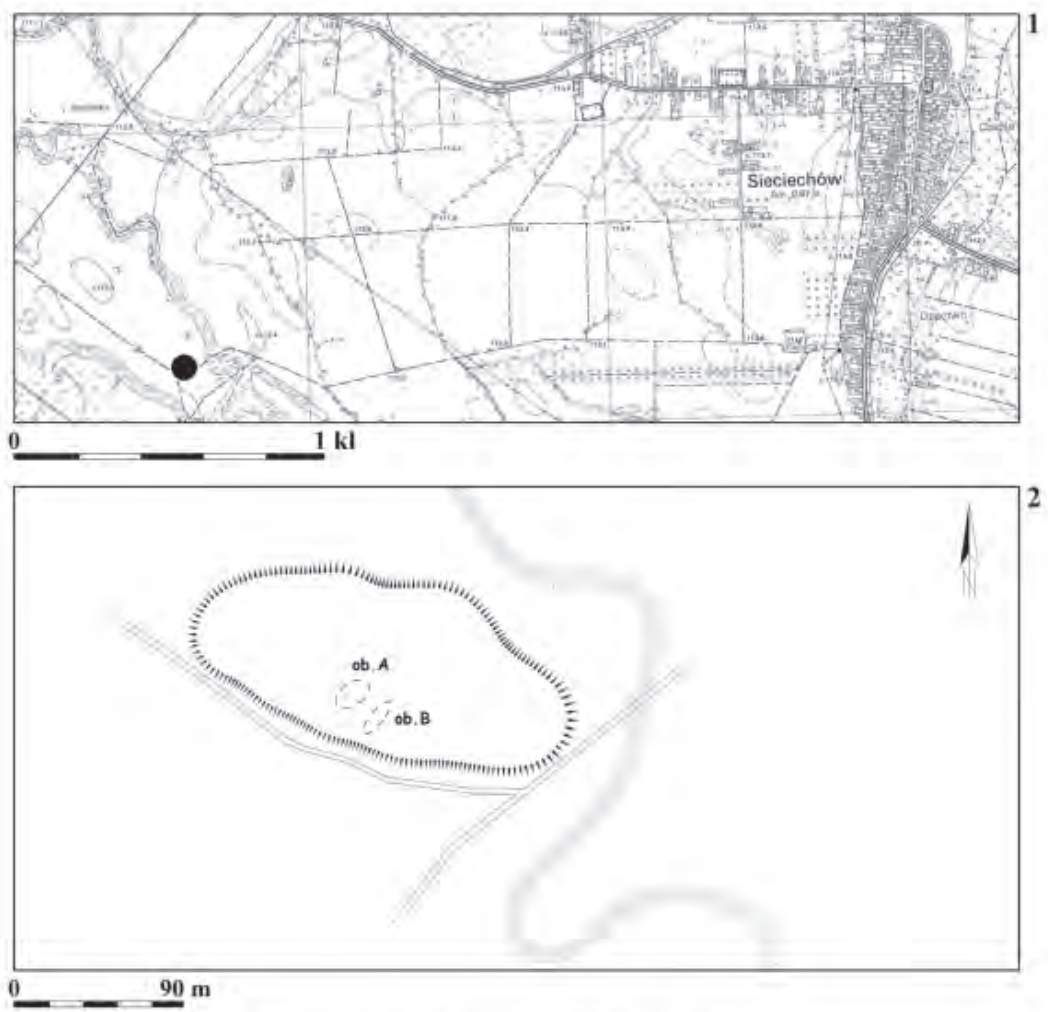

TYPOLOGIA WYLEWÓW NACZYŃ
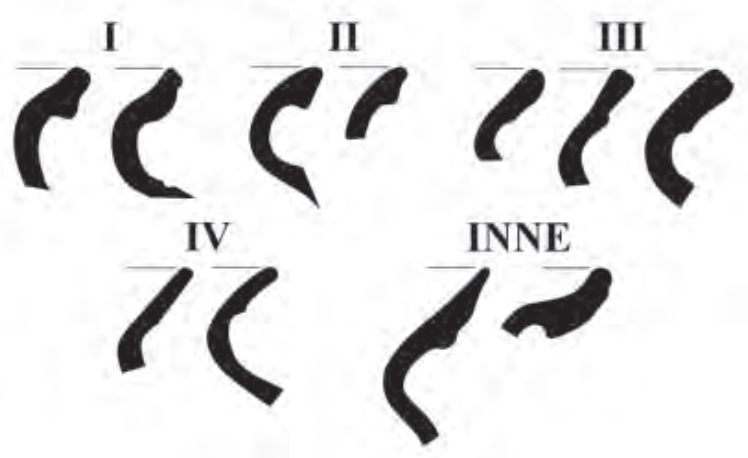

Tab. I. Sieciechów-Wójtowa Góra, pow. Kozienice, woj. mazowieckie:

1 - lokalizacja stanowiska, 2 - plan sytuacyjny stanowiska (Źródło: rys. i oprac. map Ł. Reczulski) 


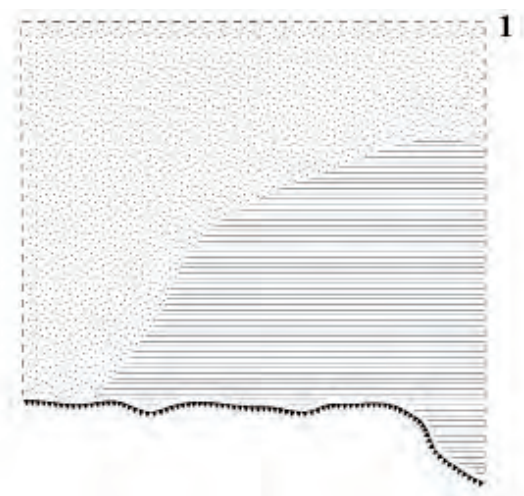

1
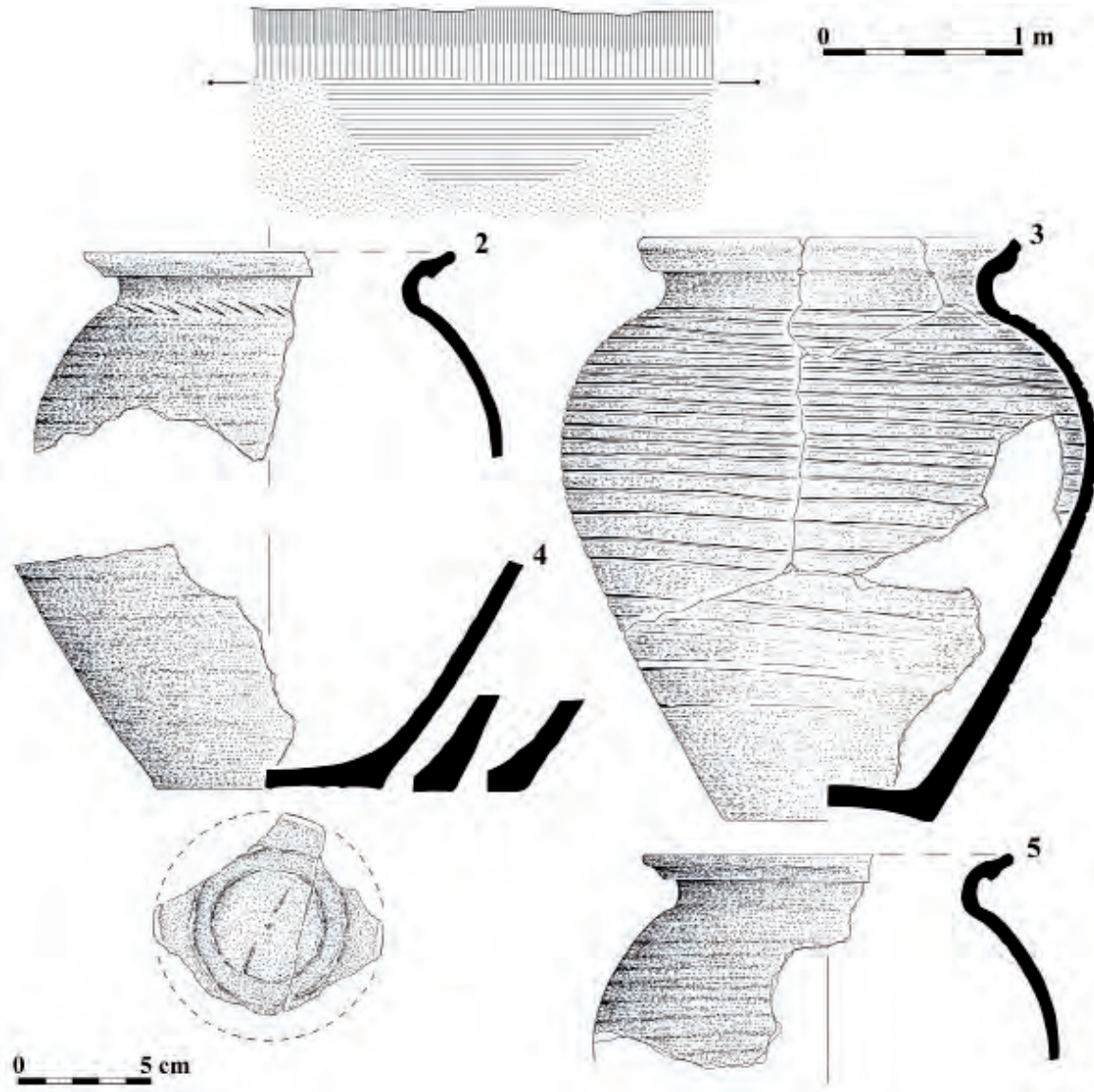

Tab. II. Sieciechów-Wójtowa Góra, pow. Kozienice, woj. mazowieckie: A - calec, B - wypełnisko obiektu, C - darń, D - zarys piaśnicy, 1 - plan i profil obiektu, 2-5 - wybór ceramiki z obiektu A (Źródło: oprac. materiału i rys. Ł. Reczulski) 

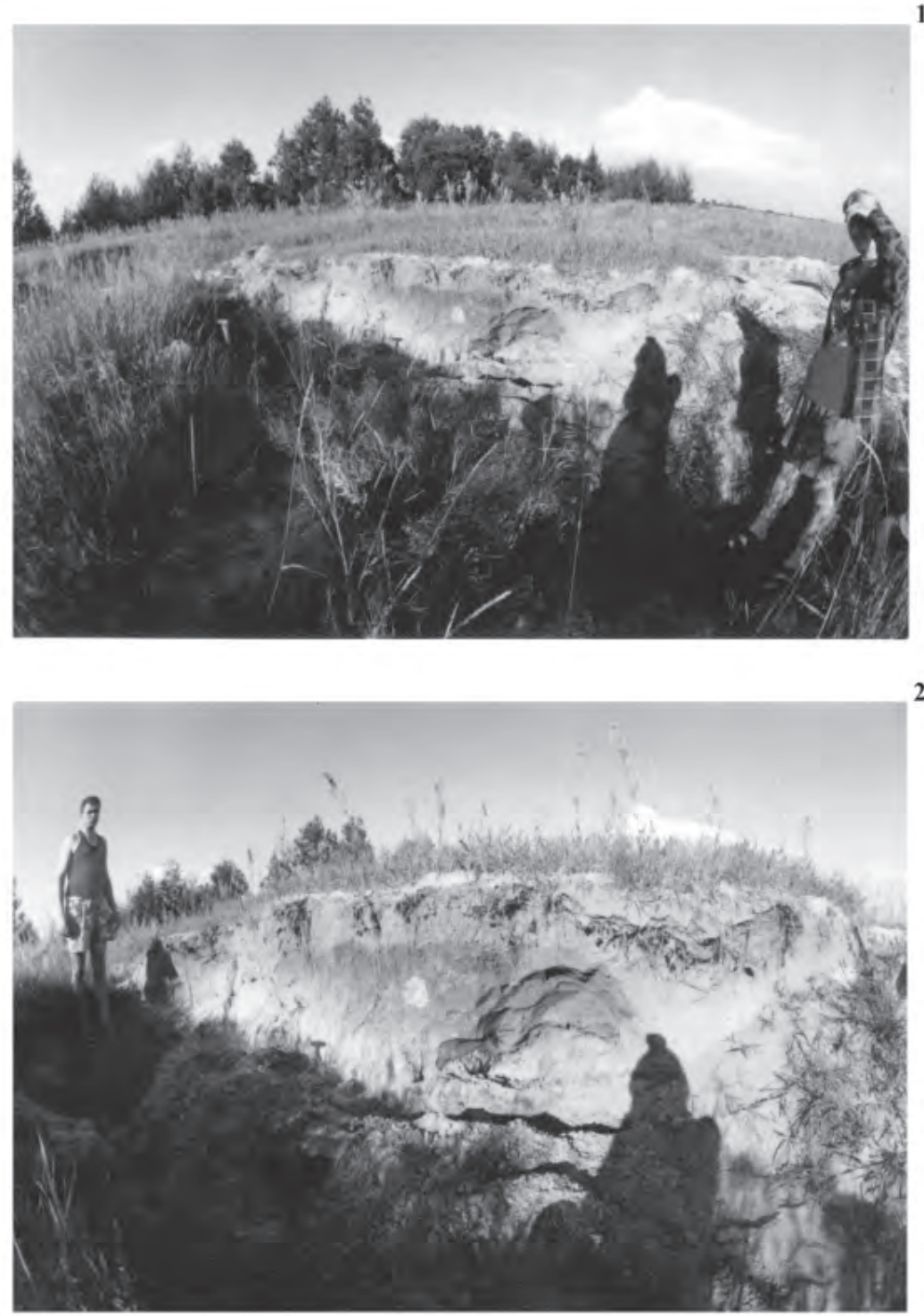

Tab. III. Sieciechów-Wójtowa Góra, pow. Kozienice, woj. mazowieckie: 1-2 - profil obiektu B (Źródło: S. Siek) 

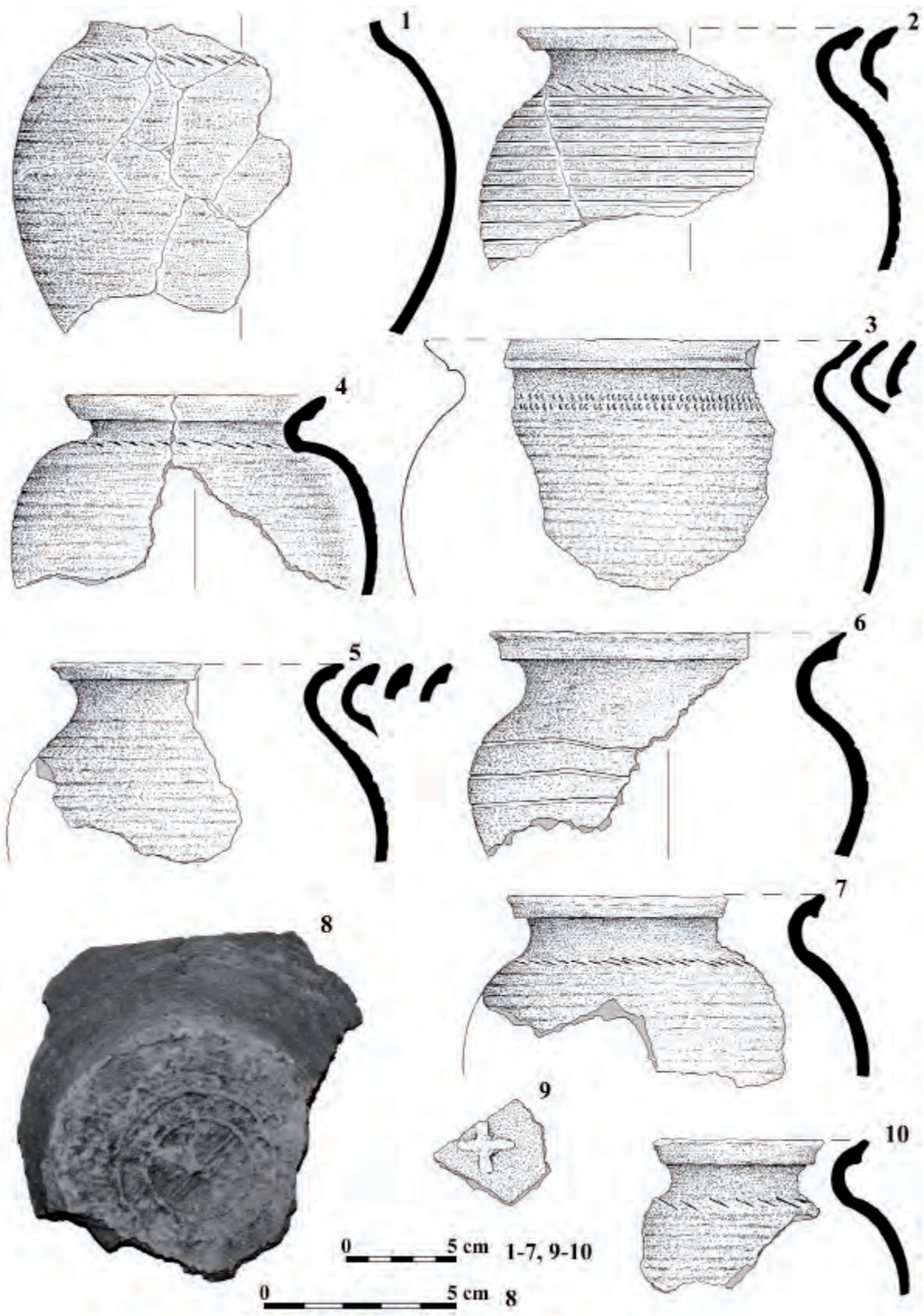

Tab. IV. Sieciechów-Wójtowa Góra, pow. Kozienice, woj. mazowieckie:

1-10 - wybór ceramiki z obiektu B

(Źródło: oprac. materiału, fot. i rys. Ł. Reczulski) 